\title{
Evaluation on Consumer Behavior
}

\author{
R. Selva, Magdalene Peter, Anitha. K
}

\begin{abstract}
Client direct is the examination of individuals, get-togethers, or affiliations and all of the activities related with the purchase, use and move of product and ventures, including the purchaser's eager, mental and social responses that go previously or seek after these activities. Purchaser direct rose during the 1940s and 50s as an obvious sub-discipline in the displaying area.

Customer direct is a between disciplinary social science that blends segments from mind look into, human science, social human examinations, human sciences, ethnography, displaying and money related perspectives, especially social monetary angles. It examines how sentiments, mindsets and tendencies impact buying conduct. Characteristics of individual buyers, for instance, economics, character lifestyles and direct factors, for instance, use rates, use occasion, unwaveringness, brand advancement, preparation to give referrals, attempting to appreciate people's needs and usage are inside and out inspected in formal examinations of purchaser lead
\end{abstract}

Key words: ethnography, unwaveringness, purchaser lead

\section{INTRODUCTION}

\section{A. Consumer Behavior}

Buyer conduct is the investigation of people, gatherings, or an association and the procedure they use to choose, use, arrange and secure of items, thoughts, administrations or experience to fulfill needs and the effect that these procedure have on the shopper and society. [1],[3],[5]

\section{B. Research Design:}

Research design is connection between what has been established and what is to be done in the conduct of the survey for realization of the objective. [19],[21],[23] The research design used in this study was descriptive research design.

C. Statistical Tools: [2 ],[ 4],[6]

4.2.1 Sample size

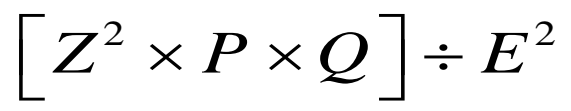

Table No: 1 Why Do You Prefer To Shop In Retail Outlet

Revised Manuscript Received on July 22, 2019.

R.SelvaDepartment of MBA,Bharath institute of Higher Education \& Research,Tamilnadu,India Email: selvar@yahoo.com

Magdalene Peter, Assistant Professor, Department of MBA,Bharath institute of Higher Education \& Research,Tamilnadu,India Email: magdalene.bsb@gmail.com

Anitha.K, Department of Civil,Bharath institute of Higher Education \& Research,Tamilnadu,IndiaEmail: anithakrish26@yahoo.co.in

\section{RESULTS \&DISCUSSION}

\begin{tabular}{|l|l|l|l|}
\hline S.NO & PARTICTZARS & RESPONDENTS & PERCENTAGE \\
\hline 1 & BrandVanety & 20 & 18.18 \\
\hline 2 & Ambience & 7 & 6.36 \\
\hline 3 & Location & 15 & 13.63 \\
\hline 4 & Time Saving & 26 & 23.63 \\
\hline 5 & Services & 21 & 19.09 \\
\hline 6 & Avalability of every item & 21 & 19.09 \\
\hline & Total & 110 & $100 \%$ \\
\hline
\end{tabular}

Chart No: 1 Why Do You Prefer To Shop In Retail Outlet

\section{RESPONDENTS}

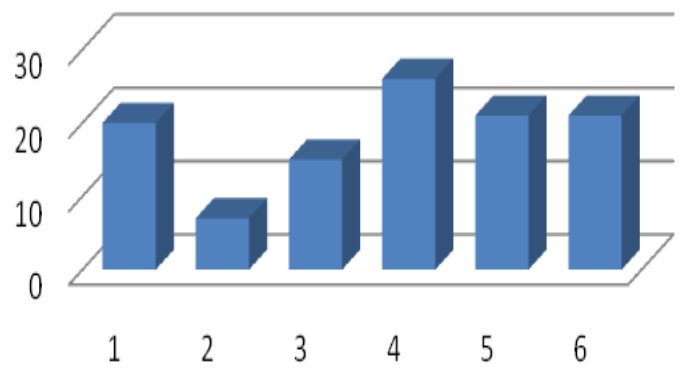

\section{- RESPONDENTS}

Table No: 2 What Is The Primary Purpose To Visit The Retail Outlets?

\begin{tabular}{|l|l|l|l|}
\multicolumn{5}{|l|}{} \\
\hline S.N0 & PARTICULARS & RESPODENCE & PERCENTAGE \\
\hline 1 & Leisure time activity & 14 & 12.72 \\
\hline 2 & $\begin{array}{l}\text { Purchase of special } \\
\text { products }\end{array}$ & 14 & 12.72 \\
\hline 3 & Children's demand & 15 & 13.63 \\
\hline 4 & $\begin{array}{l}\text { Purchase of general } \\
\text { products }\end{array}$ & 32 & 29.09 \\
\hline 5 & To buy monthly provisions & 28 & 25.45 \\
\hline 6 & To buy for daily needs & 7 & 6.36 \\
\hline & Total & 110 & $100 \%$ \\
\hline
\end{tabular}




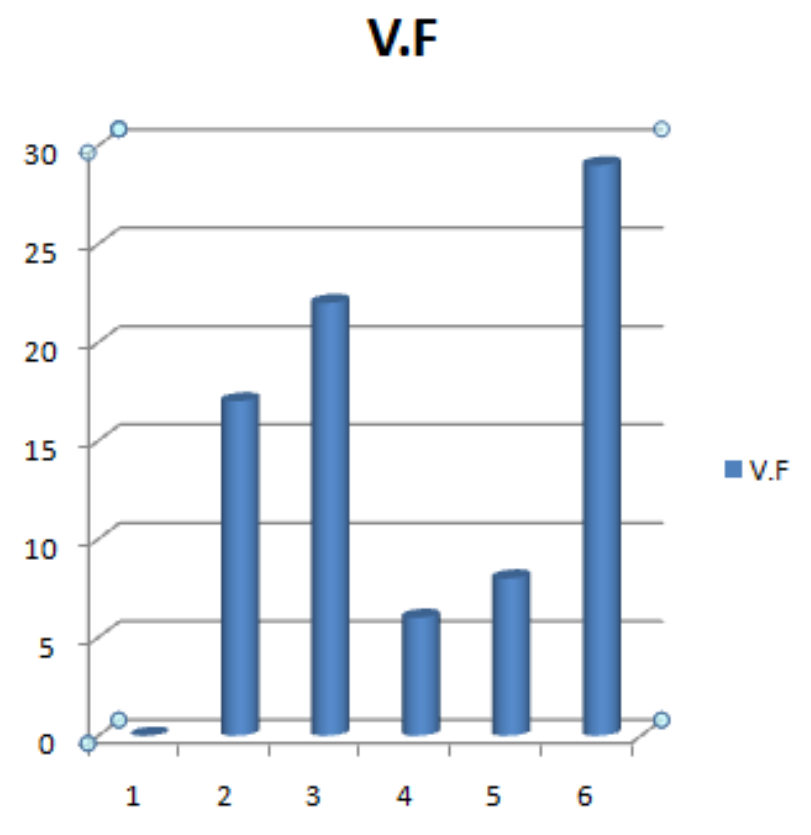

FIG 2: WHAT IS THE PRIMARY PURPOSE TO VISIT THE RETAIL OUTLETS

TABLE NO: 3 Which Outlets Do You Consider While Shopping

\begin{tabular}{|l|l|l|l|l|l|l|l|}
\hline & & V.F & F & R & V.R & N \\
\cline { 3 - 7 } S.NO & \multirow{2}{*}{ PARTICULARS } & \multicolumn{2}{|l|}{ RESPONDENCE } \\
\hline 1 & Reliance & 17 & 15 & 19 & 7 & 52 \\
\hline 2 & Big Bazaar & 22 & 18 & 14 & 7 & 49 \\
\hline 3 & More & 6 & 7 & 11 & 19 & 67 \\
\hline 4 & Heritage & 8 & 15 & 14 & 8 & 65 \\
\hline 5 & Saravana stores & 29 & 19 & 12 & 9 & 41 \\
\hline 6 & Nilgigis & 8 & 14 & 16 & 13 & 59 \\
\hline 7 & Lifestyle & 10 & 12 & 9 & 7 & 72 \\
\hline 8 & $\begin{array}{l}\text { Local } \\
\text { Neighborhood } \\
\text { store }\end{array}$ & 60 & 28 & 6 & 3 & 13 \\
\hline
\end{tabular}

\section{Chi-square}

A. Planned list before buying from a retail outlet Solution:

They do not have a planned list

(2)Alternative hypothesis:

before buying from retail outlets

They have a planned list before buying from retail outlets [8],[ 10],[12]
(1)Null hypothesis :

\begin{tabular}{|l|l|l|l|l|}
\hline 0 & $E=\frac{R . t \times C . t}{G . t}$ & {$[0-E]$} & {$[0-e]^{2}$} & $\frac{(0-E)^{2}}{E}$ \\
\hline 41 & $\frac{76 \times 68}{110}=46.98$ & .5 .98 & 35.7604 & 0.761 \\
\hline 35 & $\frac{76 \times 42}{110}=29.01$ & 5.99 & 35.8801 & 1.236 \\
\hline 27 & $\frac{34 \times 68}{110}=21.01$ & 5.99 & 35.8801 & 1.707 \\
\hline 7 & $\frac{34 \times 42}{110}=12.98$ & .598 & 35.7604 & 2.755 \\
\hline & & & & 6.459 \\
\hline
\end{tabular}

$\boldsymbol{\aleph}^{2}=\in\left[\frac{(O-E)^{2}}{E}\right]={ }_{6.459}$

Calculated value $=6.459$

Degree of freedom:

$$
\begin{aligned}
& \mathrm{V}=[\mathrm{r}-1][\mathrm{c}-1] \\
& \mathrm{V}=[2-1][2-1] \\
& \mathrm{V}=1 * 1 \quad \mathrm{~V}=1
\end{aligned}
$$

Table value $=3.84$ (constant)

Calculated value $>$ table value

It is not significant

So alternative hypothesis is accepted

The critical value of $x^{2}=5.99$ at $\mathrm{x}=0.05$ and $\mathrm{df}=2$. Since the calculated value of $x^{2}=6.459$ are more than critical value so the null hypothesis is rejected.

Conclusion: They have a planned list before buying from retail outlets [7],[9],[11]

B. Retail outlets offer any special discount on prices

\begin{tabular}{|l|l|l|l|l|}
\hline 0 & $E=\frac{R . t \times C . t}{G . t}$ & {$[O-E]$} & {$[O-e]^{2}$} & $\frac{(O-E)^{2}}{E}$ \\
\hline 28 & $\frac{49 \times 51}{75}=33.32$ & -5.32 & 27.64 & 0.8295 \\
\hline 21 & $\frac{49 \times 24}{75}=15.68$ & 5.32 & 27.64 & 1.7627 \\
\hline 23 & $\frac{26 \times 51}{75}=17.68$ & 5.32 & 27.64 & 1.5633 \\
\hline 3 & $\frac{26 \times 24}{75}=8.32$ & -5.32 & 27.64 & 3.3221 \\
\hline & & & & 7.4776 \\
\hline
\end{tabular}

$\aleph^{2}=\in\left[\frac{(O-E)^{2}}{E}\right]=7.4776$

Calculated value $=7.4776$

Degree of freedom:

$$
\begin{aligned}
& \mathrm{V}=[\mathrm{r}-1]] \mathrm{c}-1] \\
& \mathrm{V}=[2-1][2-1] \\
& \mathrm{V}=1 * 1 \\
& \mathrm{~V}=1
\end{aligned}
$$

Table value $=3.84$ (constant)

Calculated value $>$ table value It is not significant

So alternative hypothesis is accepted 
The critical value of $x^{2}=5.99$ at $\mathrm{x}=0.05$ and $\mathrm{df}=2$. Since the calculated value of

$x^{2}=7.4776$ is more than critical value so the null hypothesis is rejected. [20],[22], [24]

Conclusion: The retail outlets offer special discounts on prices [13], [15], [17]

\section{CONCLUSION}

The research findings of this study are as follows:

People preferred to shop in retail outlets for time saving. Majority of respondents said the primary purpose to visit the retail outlets was to purchase of general products. Most of the respondents said that they visited retail outlets for weekend outing. [26],[28],[30].Majority of respondents said they visited the retail outlets thrice in a month. Majority of respondents said that definitely they had a planned list before buying from retail outlets. $10 \%-30 \%$ of their monthly budget they are shopping from these retail outlets. Majority of respondents said that shopping in retail outlets the monthly expenditure remains the same. Majority of respondents said that there is only small space in the retail outlets for moving around the shop. Majority of respondents said that the representative interaction in retail market is good. Majority of respondents said that discount and free gifts are intimated for them in retail outlets. Majority of respondents said that they are neutrally satisfied with the customer service department in the retail outlets. They say that retail outlets offer special discount on prices on buy one get one free offer. Majority of respondents said that they are satisfied with the billing, parking facility, product price range, product quality and quantity, delivery facility and mode of payment. [14],[ 16], [18]

The research findings fulfilled the objective of doing the empirical study. [25],[27],[29]

\section{REFERENCES}

1) BharthVajan R., Ramachandran S.,Psychographic dimensions of training,2016,International Journal of Pharmacy and Technology,V-8,I-4,P-23727-23729

2) Balakrishnan P., Bharthvajan R.,A study on human resource planning in hospitals in Chennai City,2014,International Journal of Applied Engineering Research,V-9,I-22,P-7503-7507

3) Priyadarsini P., Bharthvajan R.,Role of emotional intelligence training programme in reducing the stress of the nurses,2014,International Journal of Applied Engineering Research,V-9,I-22,P-7411-7421

4) Kerinab Beenu G., Bharthvajan R.,Empirical analysis on the cosmetic buying behavior of young women in South India,2014,International Journal of Applied Engineering Research,V-9,I-22,P-7361-7366

5) Balakrishnan P., Bharthvajan R.,Whistling in the wind,2014,International Journal of Applied Engineering Research,V-9,I-22,P-7586-7593

6) Krishnan B., Peter M.,Health hazards of Indian Bpo employee-an alarming issue,2014,International Journal of Applied Engineering Research,V-9,I-22,P-7336-7341

7) Kerinab Beenu G.H., Peter M.,Role of insurance in economic development,2014,International Journal of Applied Engineering Research,V-9,I-22,P-7532-7539

8) Balakrishnan P., Peter M., Priyadarsini P.,Efficiency of safety measures for wellbeing of employees in manufacturing industry,2014,International Journal of Applied Engineering Research,V-9,I-22,P-7376-7382

9) Anbarasi M., Praveen Kumar S.,Online sales promotions of herbal products and its effectiveness towards tanisha.com,2019,Indian Journal of Public Health Research and Development,V-10,I-1,P-195-200

10) Anbarasi M., Praveen Kumar S.,Various online marketing and promotions strategies to improve the validation towards the organic products in the pharmaceutical sectors,2019,Indian Journal of Public Health Research and Development,V-10,I-1,P-263-269
11) Loganathan R., Praveen Kumar S.,Grievance handling a key factor for solving issues of employees in an organization,2014,International Journal of Applied Engineering Research,V-9,I-22,P-7483-7491

12) Loganathan R., Praveen Kumar S.,Study on preference of private label brands in super and Hypermarkets, 2014,International Journal of Applied Engineering Research,V-9,I-22,P-7327-7335

13) Smitha M., Praveen Kumar S.,Understanding stress and its managementamong the nurses in Chennai city,2014,International Journal of Applied Engineering Research,V-9,I-22,P-7560-7565

14) Kerinab Beenu G.H., Praveen Kumar S.,A study on the investment behavior of Chennai investors in mutual fund schemes,2014,International Journal of Applied Engineering Research,V-9,I-22,P-7520-7525

15) Loganathan R., Praveen Kumar S.,Retention strategies key for organizational productivity,2014,International Journal of Applied Engineering Research,V-9,I-22,P-7443-7447

16) Pavithra J., Ganesan M., Brindha G.,State wise analysis of microfinance sector in India,2016,International Journal of Pharmacy and Technology,V-8,I-4,P-23417-23432

17) Pavithra J., Ganesan M.,A comparative study on microfinance in India and abroad,2016,International Journal of Applied Business and Economic Research,V-14,I-8,P-5471-5476

18) Pavithra J., Ganesan M.,A study on awareness and impact of micro-financial schemes, 2016,International Journal of Applied Business and Economic Research,V-14,I-8,P-5449-5460

19) Senthilmurugan P., Pavithra J.,Consumer preference towards organised retailing with reference to Big Bazaar,2014,International Journal of Applied Engineering Research,V-9,I-22,P-7469-7475

20) Senthilmurugan P., Pavithra J.,Implication of social media marketing in growing healthcare industry,2014,International Journal of Applied Engineering Research,V-9,I-22,P-7448-7456

21) Loganathan R., Pavithra J.,Consumer perception towards private label brand over other brands in super markets and hypermarkets,2014,International Journal of Applied Engineering Research,V-9,I-22,P-7355-7360

22) Kerinab Beenu G., Pavithra J.,Tradeâ€"off between liquidity and profitability in logistics industry,2014,International Journal of Applied Engineering Research,V-9,I-22,P-7398-7401

23) Kerinab Beenu G., Pavithra J.,A study on the prospective consumerâ $€^{\mathbf{T M}_{S}}$ perception towards utility cars in Chennai city,2014,International Journal of Applied Engineering Research,V-9,I-22,P-7526-7531

24) Pavithra J., Dilli Babu P., Ambuli T.V.,A study on budgetary control at Maruti Service Masters, Chennai,2014,International Journal of Applied Business and Economic Research,V-12,I-2,P-151-161

25) Pavithra J., Dilli Babu P., Ambuli T.V.,A study on customer satisfaction of retro Garments Pvt Ltd, Chennai,2014,International Journal of Applied Business and Economic Research,V-12,I-2,P-381-391

26) Kerinab Beenu G.H., Pavithra J., Senthilmurugan P.,A study on the influence of promotional activities for TATA ARIA among consumers in Chennai,2014,International Journal of Applied Engineering Research,V-9,I-22,P-7572-7578

27) Vijayaragavan S.P.,An investigative expert that's general FBG sensors,International Journal of Mechanical Engineering and Technology,V-8,I-8,PP-1500-1505,Y-2017

28) Vijayaragavan S.P.,Equalization routing protocol for $\mathrm{Wi}-\mathrm{Fi}$ sensor strategy,International Journal of Mechanical Engineering and Technology,V-8,I-8,PP-1662-1666,Y-2017

29) Karthik B., Kiran Kumar T.V.U., Vijayaragavan P., Bharath Kumaran E.,Design of a digital PLL using 0.35 $\hat{\mathrm{I}}^{1 / 4} \mathrm{~m}$ CMOS technology,Middle East Journal of Scientific Research,V-18,I-12,PP-1803-1806,Y-2013

30) Kanniga E., Selvaramarathnam K., Sundararajan M.,Kandigital bike operating system,Middle - East Journal of Scientific Research,V

31) Jasmin M., Vigneshwaran T., Beulah Hemalatha S.,Design of power aware on chip embedded memory based FSM encoding in FPGA,International Journal of Applied Engineering Research,V-10,I-2,PP-4487-4496,Y-2015

32) Jasmin M.,Optimization techniques for low power VLSI circuits,Middle East Journal of Scientific Research,V-20,I-9,PP-1082-1087,Y-2014

33) Jasmin M., Vigneswaran T.,Fuzzy controller for error control of on Chip communication,2017 International Conference on Algorithms, Methodology, Models and Applications in Emerging Technologies, ICAMMAET 2017,V-2017-January,I-,PP-1-5,Y-2017 


\section{AUTHORS PROFILE}

R.Selva, student Department of MBA,Bharath institute of Higher Education \& Research,Tamilnadu,India

Magdalene Peter, Assistant Professor, Department of MBA,Bharath institute of Higher Education \& Research,Tamilnadu,India

Anitha.K, Assistant ProfessorDepartment of Civil,Bharath institute of Higher Education \& Research,Tamilnadu,India 